\title{
Increase of Regeneration Efficiency in JATROPHA CURCAS by In Vitro Culture Methods
}

\author{
Ying LIU 1,a , Jian-Nong LU ${ }^{1, b}$, Su-Fang NIU²,c , Hong-Bo ZHU ${ }^{1, d}$, Lin-Feng $\mathrm{LI}^{1, \mathrm{e}}$, \\ Yu-Zhen SHI ${ }^{1, \dagger}$, Xue-Gui YIN ${ }^{1, g^{*}}$ \\ ${ }^{1}$ Faculty of Agricultural Science, Guang Dong Ocean University, Haida Road \#1, Mazhang District, \\ 524088, Zhanjiang, Guangdong, P. R. China. \\ ${ }^{2}$ Faculty of Fisheries, Guang Dong Ocean University, Haida Road \#1, Mazhang District, 524088, \\ Zhanjiang, Guangdong, P. R. China. \\ aliuying85168@126.com, 'blujnong@163.com, cwolf0487@126.com, d39198351@qq.com, \\ ellf801@126.com, 'shyzh1102@163.com, ${ }^{\mathrm{g} y}$ inxuegui@126.com \\ ${ }^{*}$ Corresponding author
}

Keywords: Jatropha Curcas, Regeneration, Rooting, Thidiazuron.

\begin{abstract}
An effective protocol has been established to induce adventitious buds regeneration from 3 types of explants (petiole, petiolule, cotyledon petiole) of Jatropha curcas L. All the explants were dealt with high concentrations $(5-120 \mathrm{mg} / \mathrm{L})$ of TDZ solution for various soak time (5-80 min) with the regeneration frequency increased and the quality of the regenerated shoot-buds improved significantly compared with the traditional regeneration approach. The best result of adventitious buds regeneration was observed when explants were treated with $20 \mathrm{mg} / \mathrm{L}$ TDZ solution for $20 \mathrm{~min}$ before being placed on hormone-free MS medium for 30 days of culture. Moreover, addition of GA3 to the elongation medium was contributed to the prolongation of the shoot buds and the best elongate results could be gained at a concentration of $0.4 \mathrm{mg} / \mathrm{L}$. By application of the new protocol described in this paper, plant regeneration efficiency of $J$. curcas was increased observably and the culture period was shortened in 65 days.
\end{abstract}

\section{Introduction}

Jatropha curcas L. is widespread across tropical and sub-tropical areas. This woody plant has some advantages, for instance, the plant's extract can be used for production of insecticides and pharmaceutical compounds [1]. Moreover, seed oil of this tree is extremely high ( $40 \%$ to $60 \%)$, which can be applied to produce 'biodiesel' as an ideal substitute of naturally occurring petroleum [2]. However, the seed production is relative low in many cases. Therefore, in order to breed excellent $J$. curcas varieties for enhancing the seed yield, genetic transformation is considered to be an ideal solving procedure $[3,4]$.

In most common genetic transformation methods, adventitious buds regeneration from the transformed receptor (explants) is required to be an essential step. Nevertheless, most cases for plant regeneration of $J$. curcas were quite time-consuming (90-140 days) for obtaining regenerated plantlets [5]. For breeding excellent varieties of J. curcas and large-scale production of high quality planting material, high-efficiency tissue culture protocols are needed greatly. There were some reports on the plant regeneration of J. curcas, but the regeneration efficiency was barely satisfactory [6,7]. By application of the original approach in this study, an efficient protocol for gaining regenerated plantlets from several types of explants of J. curcas has been established.

\section{Materials and Methods}

\section{Plant Sources}

Mature seeds were collected sufficiently from the M-19 J. curcas trees, which were planted well in a farm of Haikou, Hainan province, China [5]. 


\section{Preparation of Explants}

Petiole explants were cut from mature J. curcas [5]. Petiolule explants were gained from 20-day-old seedlings. Both of these explants were sterilized with $2 \%$ sodium hypochlorite $(\mathrm{NaClO})$ for $20 \mathrm{~min}$ and then rinsed 5 times with sterile distilled water. Cotyledonary petiole explants were isolated from the 12-day-old sterile seedlings.

\section{Preparation of Mediums and Condition of Culture}

The same conditions of culture were suitable for all experiments. Basic Murashige and Skoog (MS) medium [8] was applied to whole experiments in this study. The medium $\mathrm{pH}$ was fit to 5.8-6.0 by $1 \mathrm{~mol} / \mathrm{L} \mathrm{NaOH}$ before the mediums were autoclaved at $1.4 \mathrm{~kg} \mathrm{~cm}-2$ for $20 \mathrm{~min}$. All mediums were placed at $25 \pm 2{ }^{\circ} \mathrm{C}$ with 12 -h photoperiod of $60-80 \mu \mathrm{mol} \mathrm{m}-2 \mathrm{~s}^{-1}$ intensity (cool white fluorescent tubes).

\section{Treatment of Explants with Thidiazuron (TDZ) Solution}

TDZ powder was dissolved with $1 \mathrm{~mol} / \mathrm{L} \mathrm{NaOH}$, which was diluted with pure water to make 0 , $5,10,20,30,60$ and $120 \mathrm{mg} / \mathrm{L} \mathrm{TDZ}$ solution, and then regulated them with $1 \mathrm{~mol} / \mathrm{L} \mathrm{HCl}$ to maintain $\mathrm{pH}$ 5.8-6.0 and conducted sterile filtration. The three kinds of explants were dipped into TDZ solutions for various time cycles $(0,5,10,20,40$ and $80 \mathrm{~min})$. After treatment, the explants were placed on bacteria free filter paper to get rid of excess liquid.

\section{Regeneration}

In order to induce regeneration of adventitious buds, explants were placed on hormone-free MS medium horizontally for 30 days of culture after dealing with TDZ solution for various time cycles. By contrast, explants were also dealt with traditional method and inoculated horizontally on MS medium contained $0,0.1,0.3,0.6$ and $1.2 \mathrm{mg} / \mathrm{L}$ TDZ for 30 days [6,7].

\section{Elongation of Shoot-buds}

For the sake of shoot-buds elongation, the regenerated adventitious buds were moved away along with the maternal tissue (explants) to MS medium contained $0.5 \mathrm{mg} / \mathrm{L}$ 6-benzyladenine (6-BA), $0.2 \mathrm{mg} / \mathrm{L}$ kinetin (KT), $0.25 \mathrm{mg} / \mathrm{L}$ indole-3-acetic acid (IAA) [6] and 0, 0.1, 0.2, 0.4, 0.6 and $0.8 \mathrm{mg} / \mathrm{L}$ gibberellic acid (GA3) for 15 days of culture.

\section{Rooting and Acclimatization}

Elongated shoots (at least $10 \mathrm{~mm}$ ) were cut from the maternal tissue and inoculated into fresh half-strength MS medium contained $0.1 \mathrm{mg} / \mathrm{L}$ indole-3-butyric acid (IBA) for 20 days of culture [9]. Plantlets were transplanted carefully to plastic bottles with soil and sterile sand at the ratio of 1:1 and placed lid with the transparent plastic film for 15 days of culture. Finally, the regenerated plants were transplanted into a culturing room (temperature $25 \pm 2{ }^{\circ} \mathrm{C}$ and relative humidity 70-80\%) for further acclimatization.

\section{Data Analysis}

All of the experiments were established in an absolutely random factorial design and repeated three times (30 explants per treatment). Data analysis was implemented by applying SPSS 17.0 software and the significantly different of data was confirmed via Duncan's multiple comparison $(p$ $\leq 5 \%$ ). The results were showed as mean value \pm standard deviation (SD).

\section{Results}

\section{Induction of Adventitious Buds Regeneration from Explants Via Conventional Methods}

From the results summarized in table 1, it's clear that the regeneration efficiency of shoot-buds was not satisfying and the buds were relatively thin and weak, the highest regeneration rate of adventitious buds was $29.02 \%-63.65 \%$ and the maximum quantity of average number of buds per 
explant was 2.78-6.58 (Table 1 and Figure A, C and E). Comprehensive view, $0.6 \mathrm{mg} / \mathrm{L}$ was the most suitable concentration.

Tab. 1 Results of various TDZ concentrations on adventitious buds regeneration from three kinds of explants of $J$. curcas via conventional method.

\begin{tabular}{|c|c|c|c|c|c|c|}
\hline \multirow[t]{2}{*}{$\begin{array}{l}\text { Concentrations of } \\
\mathrm{TDZ}(\mathrm{mg} / \mathrm{L})\end{array}$} & \multicolumn{3}{|c|}{$\begin{array}{l}\text { Regeneration } \\
\text { rate }(\%)\end{array}$} & \multicolumn{3}{|c|}{$\begin{array}{l}\text { Average number of } \\
\text { buds per explant }\end{array}$} \\
\hline & Petiole & Petiolule & Cotyledon petiole & Petiole & Petiolule & Cotyledon petiole \\
\hline 0 & $0 \mathrm{~d}^{*}$ & Od & od & $0 \mathrm{c}$ & Od & Od \\
\hline 0.1 & $14.20 \pm 2.83 c$ & $52.70 \pm 2.10 \mathrm{~b}$ & $12.72 \pm 2.85 \mathrm{c}$ & $1.94 \pm 0.36 \mathrm{~b}$ & $5.24 \pm 0.48 \mathrm{~b}$ & $2.27 \pm 0.25 \mathrm{c}$ \\
\hline 0.3 & $22.69 \pm 2.12 b$ & $60.03 \pm 4.41 \mathrm{a}$ & $28.69 \pm 5.73 \mathrm{~b}$ & $2.36 \pm 0.27 \mathrm{ab}$ & $6.12 \pm 0.54 \mathrm{a}$ & $3.38 \pm 0.54 \mathrm{~b}$ \\
\hline 0.6 & $29.02 \pm 2.64 \mathrm{a}$ & $63.65 \pm 3.38 \mathrm{a}$ & $41.68 \pm 3.01 \mathrm{a}$ & $2.78 \pm 0.32 \mathrm{a}$ & $6.58 \pm 0.66 \mathrm{a}$ & $4.31 \pm 0.41 \mathrm{a}$ \\
\hline 1.2 & $21.78 \pm 1.43 b$ & $41.33 \pm 3.11 \mathrm{c}$ & $33.21 \pm 2.47 \mathrm{~b}$ & $2.25 \pm 0.19 \mathrm{ab}$ & $4.23 \pm 0.32 c$ & $3.26 \pm 0.38 \mathrm{~b}$ \\
\hline
\end{tabular}

Values represent means $\pm \mathrm{SD}$ (standard deviation) of 35 explants per treatment in 3 independent experiments.

* Data in the same column followed by various letters are significant difference (Duncan's test at $\mathrm{p} \leq 5 \%$ level).
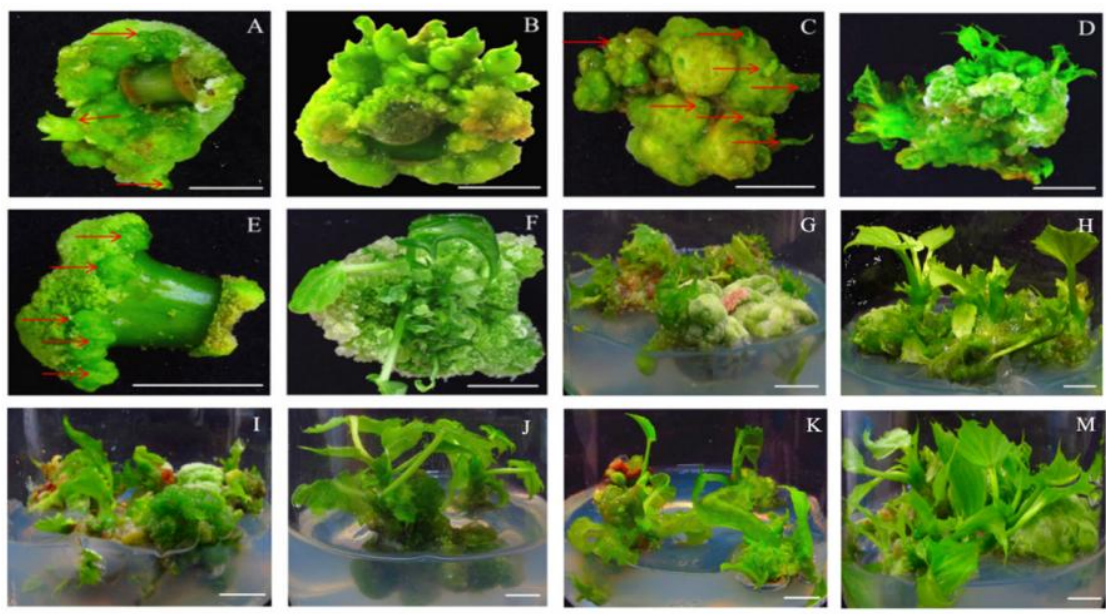

Fig. 1 Effect of adventitious buds regeneration and elongation from various explants of $J$. curcas via conventional approach and new method

(A) Petiole, (C) petiolule and (E) cotyledon petiole were placed onto MS medium contained 0.6 $\mathrm{mg} / \mathrm{L} \mathrm{TDZ}$ for induction of adventitious buds regeneration after 30 days of culture, red arrows indicated the regenerated buds, which were counted but were not easily observed in the photographs (bars $=0.5 \mathrm{~cm}$ ); (B) Petiole, (D) petiolule and (F) cotyledon petiole were inoculated onto hormone free MS medium for induction of adventitious buds regeneration for 30 days of culture after treatment with $20 \mathrm{mg} / \mathrm{L} \mathrm{TDZ}$ solution for $20 \mathrm{~min}$ ( $\mathrm{bar}=0.5 \mathrm{~cm})$; Shoot buds regenerated from

(G) petiole, (I) petiolule, (K) cotyledon petiole via conventional method, and adventitious buds regenerated from $(\mathrm{H})$ petiole, $(\mathrm{J})$ petiolule, $(\mathrm{M})$ cotyledon petiole by applying new approach were all placed on elongation medium contained $0.4 \mathrm{mg} / \mathrm{L} \mathrm{GA} 3$ for 15 days of culture (bar $=1 \mathrm{~cm}$ ).

\section{Regeneration of Adventitious Buds from Explants Dealt with TDZ before Culture}

As shown in Table 2, the regeneration rate of adventitious buds and the number of induced shoot buds per explant were also affected by the TDZ solution concentration observably. The highest rate of shoot buds regeneration (65.78\%-91.36\%) and the highest quantity of regenerated shoot buds per explant (6.77-12.67) were gained, when $20 \mathrm{mg} / \mathrm{L}$ of TDZ solution was used in treatment; Meanwhile, the regenerated buds were healthy and strong visibly (Table 2 and Figure 1 (B, D and F)). 
Tab. 2 Results of various TDZ concentrations on adventitious buds regeneration from three kinds of explants of J. curcas.

\begin{tabular}{|c|c|c|c|c|c|c|}
\hline \multirow[t]{2}{*}{$\begin{array}{l}\text { Concentrations of TDZ } \\
(\mathrm{mg} / \mathrm{L})\end{array}$} & \multicolumn{3}{|c|}{$\begin{array}{l}\text { Regeneration } \\
\text { rate }(\%)\end{array}$} & \multicolumn{3}{|c|}{$\begin{array}{l}\text { Average number of } \\
\text { buds per explant }\end{array}$} \\
\hline & Petiole & Petiolule & Cotyledon petiole & Petiole & Petiolule & Cotyledon petiole \\
\hline 0 & $0 \mathrm{e}^{*}$ & Oe & of & Oe & of & of \\
\hline 5 & $28.89 \pm 1.93 \mathrm{~d}$ & $64.77 \pm 4.06 \mathrm{c}$ & $43.21 \pm 2.89 \mathrm{~d}$ & $3.84 \pm 0.24 d$ & $7.25 \pm 0.42 c$ & $5.89 \pm 0.46 \mathrm{~d}$ \\
\hline 10 & $43.33 \pm 3.33 c$ & $77.78 \pm 3.09 \mathrm{~b}$ & $52.57 \pm 3.09 \mathrm{c}$ & $4.62 \pm 0.05 c$ & $8.46 \pm 0.35 b$ & $7.18=0.48 c$ \\
\hline 20 & $65.78 \pm 1.54 a$ & $91.36 \pm 3.66 \mathrm{a}$ & $88.42 \pm 3.67 \mathrm{a}$ & $6.77 \pm 0.51 \mathrm{a}$ & $12.01 \pm 0.46 a$ & $12.67 \pm 0.42 \mathrm{a}$ \\
\hline 30 & $59.19 \pm 1.40 \mathrm{~b}$ & $79.07 \pm 4.65 \mathrm{~b}$ & $72.19 \pm 2.72 b$ & $5.80 \pm 0.31 \mathrm{~b}$ & $9.19 \pm 0.52 b$ & $9.27 \pm 0.52 b$ \\
\hline 60 & $55.18 \pm 3.39 \mathrm{~b}$ & $63.33 \pm 3.67 \mathrm{c}$ & $56.08 \pm 4.35 c$ & $5.33 \pm 0.33 b$ & $6.18 \pm 0.83 \mathrm{~d}$ & $7.71=0.81 \mathrm{c}$ \\
\hline 120 & $45.19 \pm 2.79 c$ & $24.49 \pm 2.46 \mathrm{~d}$ & $27.45 \pm 3.21 \mathrm{e}$ & $4.36 \pm 0.69 \mathrm{~cd}$ & $3.04 \pm 0.38 \mathrm{e}$ & $4.58 \pm 0.39 \mathrm{e}$ \\
\hline
\end{tabular}

Values represent means $\pm \mathrm{SD}$ (standard deviation) of 35 explants per treatment in 3 independent experiments. All the explants were treated with TDZ

* Data in the same column followed by various letters are significant difference (Duncan's test at $\mathrm{p} \leq 5 \%$ level).

In order to investigate the influence of handling time on adventitious buds regeneration, explants were immersed in $20 \mathrm{mg} / \mathrm{L} \mathrm{TDZ}$ solution for different time period before placed on hormone-free MS medium. From the results summed up in table 3, it's very clear that the optimal processing time was $20 \mathrm{~min}$, and then the best regeneration rate $(65.78 \%-91.36 \%)$ and the maximum number of regenerated buds per explant (6.76-12.67) were achieved (Table 3 and Figure 1 (B, D and F)). Comparing to the conventional approach in this study, these regeneration rate and average number of buds per explant were increased respectively by $28.01 \%-47.06 \%$ and $3.99-8.37$, and these regenerated buds were more vigorous (Table 1, Table 3 and Figure $1 \mathrm{~A}-\mathrm{F}$ ).

Tab. 3 Results of various handling time on adventitious buds regeneration from three kinds of explants of J. curcas.

\begin{tabular}{|c|c|c|c|c|c|c|}
\hline \multirow[t]{2}{*}{ Treatment duration } & \multicolumn{3}{|c|}{$\begin{array}{l}\text { Regeneration } \\
\text { rate }(\%)\end{array}$} & \multicolumn{3}{|c|}{ Average number of } \\
\hline & Petiole & Petiolule & Cotyledon petiole & Petiole & Petiolule & Cotyledon petiole \\
\hline 0 & $0 \mathrm{~d}^{*}$ & od & Od & $0 \mathrm{e}$ & Od & $0 \mathrm{~d}$ \\
\hline 5 & $42.99 \pm 1.39 \mathrm{c}$ & $57.12 \pm 2.63 \mathrm{c}$ & $50.53 \pm 6.37 \mathrm{c}$ & $4.34 \pm 0.15 c$ & $6.55 \pm 0.33 c$ & $6.62 \pm 0.78 c$ \\
\hline 10 & $54.76 \pm 4.12 b$ & $73.12 \pm 4.27 \mathrm{~b}$ & $65.32 \pm 4.28 \mathrm{~b}$ & $5.35 \pm 0.39 b$ & $7.58 \pm 0.51 b$ & $8.12 \pm 0.69 b$ \\
\hline 20 & $65.78 \pm 1.54 a$ & $91.36 \pm 3.66 \mathrm{a}$ & $88.42=3.67 a$ & $6.76 \pm 0.51 \mathrm{a}$ & $12.01 \pm 0.46 \mathrm{a}$ & $12.67 \pm 0.42 a$ \\
\hline 40 & $54.24 \pm 3.81 \mathrm{~b}$ & $74.44 \pm 4.24 \mathrm{~b}$ & $67.88 \pm 4.96 b$ & $4.91 \pm 0.37 b$ & $8.04 \pm 0.57 b$ & $8.35=0.71 b$ \\
\hline 80 & $39.03 \pm 4.09 c$ & $55.47 \pm 3.19 c$ & $54.13=5.22 c$ & $3.11 \pm 0.03 \mathrm{~d}$ & $6.05 \pm 0.28 \mathrm{c}$ & $6.74=0.59 c$ \\
\hline
\end{tabular}

Values represent means \pm SD (standard deviation) of 35 explants per treatment in 3 independent experiments.

* Data in the same column followed by various letters are significant difference (Duncan's test at $\mathrm{p} \leq 5 \%$ level).

\section{Effects of GA3 on the Elongation of the Regenerated Shoot-buds}

As shown in Table 4, the concentration of GA3 influenced the elongation of the shoot-buds significantly. From the results summarized in table 4, it's explicit clear that the most suitable concentration of GA3 was $0.4 \mathrm{mg} / \mathrm{L}$, and the best results of shoot-buds elongation from 
conventional approach $(1.09-1.17 \mathrm{~cm})$ and treatment of high TDZ solution $(1.79-1.81 \mathrm{~cm})$ were obtained separately (Table 4). Furthermore, the effect of elongation of the regenerated shoot-buds from TDZ treatment protocol has a better overall view than the buds from conventional approach (Table 4 and Figure 1 G-M).

Tab. 4 Results of various GA3 concentrations on shoot buds elongation.

\begin{tabular}{|c|c|c|c|c|c|c|}
\hline \multirow[t]{2}{*}{$\begin{array}{l}\text { Concentration of } \mathrm{GA} 3 \\
(\mathrm{mg} / \mathrm{L})\end{array}$} & \multicolumn{2}{|c|}{$\begin{array}{l}\text { Buds from conventional } \\
\text { approach }\end{array}$} & \multicolumn{4}{|c|}{$\begin{array}{l}\text { Buds from treatment of high TDZ } \\
\text { solution }\end{array}$} \\
\hline & Petiole & Petiolule & Cotyledon petiole & Petiole & Petiolule & Cotyledon petiole \\
\hline 0 & $0.54 \pm 0.11 \mathrm{c}^{*}$ & $0.55 \pm 0.10 \mathrm{c}$ & $0.51 \pm 0.13 \mathrm{c}$ & $0.91 \pm 0.07 d$ & $0.93 \pm 0.12 \mathrm{~d}$ & $0.82 \pm 0.08 \mathrm{~d}$ \\
\hline 0.1 & $0.74 \pm 0.13 b$ & $0.76 \pm 0.10 \mathrm{~b}$ & $0.78 \pm 0.10 \mathrm{~b}$ & $1.30 \pm 0.09 c$ & $1.25 \pm 0.08 c$ & $1.12 \pm 0.17 \mathrm{c}$ \\
\hline 0.2 & $0.83 \pm 0.09 \mathrm{~b}$ & $0.87 \pm 0.11 \mathrm{~b}$ & $0.91 \pm 0.08 \mathrm{~b}$ & $1.48 \pm 0.08 \mathrm{~b}$ & $1.43 \pm 0.10 \mathrm{~b}$ & $1.31 \pm 0.11 \mathrm{c}$ \\
\hline 0.4 & $1.09 \pm 0.12 a$ & $1.14 \pm 0.09 \mathrm{a}$ & $1.17 \pm 0.09 \mathrm{a}$ & $1.80 \pm 0.11 \mathrm{a}$ & $1.81 \pm 0.06 \mathrm{a}$ & $1.79 \pm 0.08 \mathrm{a}$ \\
\hline 0.6 & $0.91 \pm 0.09 \mathrm{~b}$ & $0.87 \pm 0.09 \mathrm{~b}$ & $0.94 \pm 0.11 b$ & $1.63 \pm 0.08 \mathrm{ab}$ & $1.66 \pm 0.13 \mathrm{ab}$ & $1.61 \pm 0.06 \mathrm{~b}$ \\
\hline 0.8 & $0.83 \pm 0.11 \mathrm{~b}$ & $0.78 \pm 0.15 b$ & $0.85 \pm 0.13 b$ & $1.55 \pm 0.10 \mathrm{~b}$ & $1.54 \pm 0.09 \mathrm{~b}$ & $1.53 \pm 0.07 \mathrm{~b}$ \\
\hline
\end{tabular}

Values represent means $\pm \mathrm{SD}$ (standard deviation) of 35 explants per treatment in 3 independent experiments.

* Data in the same column followed by various letters are significant difference (Duncan's test at $\mathrm{p} \leq 5 \%$ level).

Finally, the elongated shoots were inoculated into rooting medium for 20 days of culture, and the complete plant were yielded smoothly (Figure. 2A) and then transplanted in plastic bottle and pot for further growth (Figure. 1B and C).
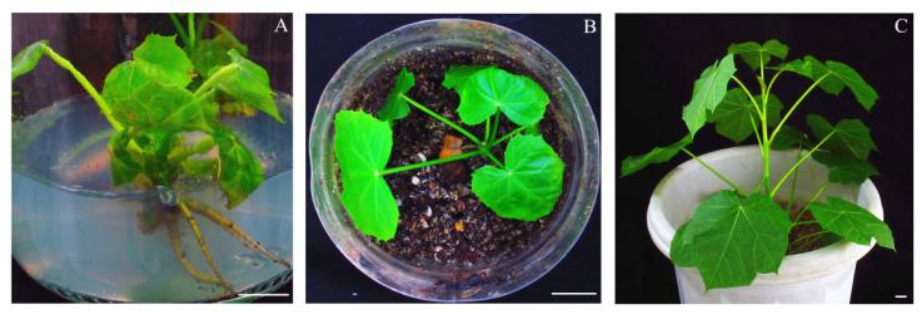

Fig. 2 Rooting of elongated shoot-buds and transplantation of the regenerated plants to the soil. (A) Rooting of elongated shoot buds on half-strength MS medium contained $0.1 \mathrm{mg} / \mathrm{L}$ IBA after 20 days of culture; (B) 20-day-old acclimatized plant; (C) a intact plant was transplanted in a flowerpot for further acclimatization. (bars $=1 \mathrm{~cm}$ )

\section{Discussion}

Cytokinin is an essential factor for the induction of shoot-buds formation in most cases [7]. In the process of woody plant tissue culture, TDZ is a powerful cytokinin [11]. Our results showed that cytokinin might be only needed for a short-term during induction of adventitious buds regeneration. More better quality of the regenerated buds (bigger buds) was gained by the new method, which was in agreement with our preceding work in soybeans and J. curcas closely $[5,10]$. Moreover, further culture of the regenerated buds showed that the regenerated buds were elongated easily. However, low regeneration effect and inferior elongation results of shoot-buds were yielded subsequently via conventional approaches.

When the explants were treated with high concentrations of cytokinin solution, the regeneration effect of adventitious buds would be increased obviously [5,10]. Nevertheless, it's still unclear that why high concentration of cytokinin solutions had the positive effect on facilitating shoot buds regeneration. Our study suggested that the induction of adventitious buds regeneration might not always need cytokinin during the entire culture cycle; when the signal of cell division for 
adventitious buds regeneration was motivated, the remanent cytokinin might be not necessary in the mediums. On the contrary, long presence in the mediums might have some adverse impacts to inhibit the development of adventitious buds.

\section{Summary}

A resultful in vitro culture method for gaining derived plants from three kinds of explants of $J$. curcas was established successfully. Regeneration effect of adventitious buds was improved markedly, an intact plantlet could be acquired in 65 days of culture via the described culture method in the present study, but at 90-140 days of culture by traditional protocols. This efficiency and reproducible approach might be put into use to the acquisition of genetically modified crops via Agrobacterium/biolistic bombardment-mediated transformation.

\section{Acknowledgements}

This work were supported by the National Science Foundation of P. R. China (31271759), the Project of Science and Technology of Guangdong province (2013B060400024 and 2014A020208116), the Program for Scientific Research Start-up Funds of Guangdong Ocean University, the Project of Science and Technology of Zhangjiang city (2016B101), and the Project of Enhancing School with Innovation of Guangdong Ocean University (2015KQNCX054).

\section{References}

[1] K. Openshaw: Biomass Bioenerg. Vol. 19 (2000), p. 1-15.

[2] A.A.A. Liberalino, E.A. Bambirra, T. Moraes-Santos and E.C. Vieira: Arq. Biol. Technol. Vol. 31 (1988), p. 539-550.

[3] M.R. Li, H.Q. Li, H.W. Jiang, X.P. Pan and G.J. Wu: Plant Cell Tiss. Organ. Vol. 92 (2008), p. $173-181$.

[4] J. Qu, H.Z. Mao, W. Chen, S.Q. Gao, Y.N. Bai, Y.W. Sun, Y.F. Geng and J. Ye: Biotechnol. Biofuels. Vol. 5 (2012), p. 1-11.

[5] Y. Liu, X. Tong, W.K. Hui, T. Liu, X.Y. Chen, J. Li, C.X. Zhuang, Y.S. Yang and Z.L. Liu: Biotechnol. Biotec. Eq. Vol. 29 (2015), p. 479-488.

[6] A.C. Deore and T.S. Johnson: Plant Biotech. Rep. Vol. 2 (2008), p. 10-15.

[7] N. Kumar and M.P. Reddy: Ind. Crops Prod. Vol. 39 (2012), p. 62-68.

[8] T. Murashige and F. Skoog: Physiol. Plant. Vol. 15 (1962), p. 473-479.

[9] Y. Liu, J.N. Lu, H.B. Zhu, L.F. Li, Y.Z. Shi and X.G. Yin: Biotechnol. Biotec. Eq. 10.1080/13102818.2016.1199971.

[10]Y. Liu, L. Yu, Q. Zhang, H. Nian, Z.F. Guo and Y.S. Yang: Adv. Mater. Res. Vol. 647 (2013), p. 331-335.

[11]C.A. Huetteman and J.E. Preece: Plant Cell Tiss. Organ. Vol. 33 (1993), p. 105-119. 